\title{
PENDIDIKAN DALAM MASYARAKAT MODERN SEDERHANA
}

\author{
MESRAWATI SIMBOLON \\ SMP Budi Mulia Jakarta \\ mesrawatisimbolon@gmail.com
}

\begin{abstract}
One very basic difference between education in a simple society and modern society is a shift from the need for individuals to learn something that is agreed upon by everyone for their survival, both present and future. The greater the knowledge and complex skills to be learned, the longer it will take for the continuity of social life. The task of education in society is to arouse intellectual curiosity, that is, attention to knowledge that is separate from its practical application. This is not easy, because it requires attitude, discipline and intellect that is not pragmatic, instant and fast-paced. With the existence of educational comparisons in this society, a more balanced, critical comparison of our education system is processed. It is clear, that in education there is no bias in moving complex practices into a culture that is more complex and large and expecting results. On the other hand, the success of a simple society in taking care of certain aspects in encouraging their education will encourage us to overcome our educational problems such as the problem of integrating children into the community into their environment and arousing student interest, motivation and attention during the education period. It is necessary to look for solutions with a greater perspective and optimism.
\end{abstract}

Keywords: Education, Society, Modern, Simple.

\begin{abstract}
Abstrak: Satu perbedaan yang sangat mendasar antara pendidikan dalam masyarakat sederhana dengan masyarakat modern adalah pergeseran dari kebutuhan individu untuk mempelajari sesuatu yang disetujui oleh setiap orang untuk kelangsungan hidupnya baik masa sekarang maupun masa akan datang. Semakin besar pengetahuan dan kompleks keterampilan yang akan dipelajari maka semakin lama waktu diperlukan untuk kelangsungan kehidupan bermasyarakat. Tugas pendidikan dalam masyarakat adalah membangkitkan rasa ingin tahu intelektual, yaitu perhatian terhadap pengetahuan yang terpisah dari aplikasi praktisnya. Hal ini sangatlah tidah mudah, karena diperlukan sikap, disiplin dan intelektual yang tidak bersifat pragmatis, instant dan serba cepat. Dengan adanya perbandingan pendidikan dalam masyarakat ini dieperolah perbandingan yang lebih seimbang kritis mengenai sisstem pendidikan kita. Jelas, bahwa dalam pendidikan tidak bias memindahkan praktek-praktek yang komplek kedalam kebudayaan yang lebih komplek dan besar dan mengharapkan akan hasil. Sebaliknya sukses masyarakat sederhana dalam mengurus aspek-aspek tertentu dalam mendorong pendidikannya, akan mendorong kita untuk mengatasi masalahmasalah pendidikan kita seperti masalah mengintegrasikan anak-anak kedalam komunitas kedalam lingkungannya dan membangkitkan minat, motivasi serta perhatian siswa selama masa pendidikan merupakan permasalahan-permasalahan yang perlu dicarai solusinya dengan prespektif dan optimisme yang lebih besar.
\end{abstract}

Kata Kunci: Pendidikan, Masyarakat, Modern, Sederhana.

\section{A. Pendahuluan}

Setiap individu dalam masyarakat merupakan potensi yang harus dikembangkan untuk mendukung dan melancarkan kegiatan pembangunan dalam masyarakat tersebut. Manusia sebagai individu, sebagaimana kodratnya memiliki sifat baik maupun buruk.

EISSN 2657-0289 $\quad$ Lembaga Penelitian dan Penerbitan Hasil Penelitian Ensiklopedia $\quad 31$


Sifat-sifat yang kurang baik inilah perlu dibina dan dirubah sehingga melahirkan sifatsifat yang baik lalu dibina dan dikembangkan. Proses perubahan dan pembinaan tersebut disebut dengan pendidikan. (L. Hendrowibowo, 1994). Melalui pendidikan, manusia diharapkan menjadi individu yang mempunyai kemampuan dan keterampilan untuk secara mandiri meningkatkan taraf hiudupnya baik lahir maupun bathin serta meningkatkan peranannya sebagai individu/pribadi, warga masyarakat, warga Negara dan sebagai khalifah-Nya.

Berbicara mengenai pendidikan tidak terlepas dari sudut pandang serta pendekatan yang digunakan. Untuk melihat pendidikan secara utuh maka diperlukan suatu pendekatan system, sehingga pendidikan dilihat secara menyeluruh dan tidak lagi parsial atau pragmatis. Pendidikan merupakan suatu proses, dimana proses tersebut dapat berlangsung dimana dan kapan saja, tidak hanya dalam lingkungan yang formal seperti di sekolah atau kampus karena pendidikan tidak hanya sekolah atau kuliah. Perkembangan seseorang mulai dari kecil, remaja sampai dewasa, di sekolah, di masyarakat dan di rumah merupakan proses pendidikan yang menyeluruh.

Menurut Pannen (2001: 1) pendidikan digambarkan sebagai suatu kesatuan yang terdiri dari subsistem-subsistem dan membentuk satu sistem yang utuh. Sistem pendidikan ini memperoleh input dari masyarakat dan lingkungan serta akan memberikan output bagi masyarakat dan lingkungan tersebut. Pendidikan merupakan usaha sadar dan terencana untuk mewujudkan suasana belajar dan proses pembelajaran agar peserta didik secara aktif mengembangkan potensi dirinya untuk memiliki kekuatan spiritual, pengendalian diri, kepribadian, kecerdasan, akhlak mulia, serta keterampilan yang diperlukan dirinya, masyarakat, bangsa dan Negara..

\section{B. Metodologi Penelitian}

Metodologi penelitian ini memakai penelitian naratif. Penelitian naratif dapat dianggap sebagai metode penelitian itu sendiri tetapi juga dapat dianggap fenomena yang diteliti. Metode naratif dapat dianggap sebagai "ukuran dunia nyata" yang sesuai ketika "masalah kehidupan nyata" diselidiki. Artikel ini akan melihat bagaimana pendidikan dalam masyarakat modern sederhana.

\section{Hasil dan Pembahasan}

\section{Masyarakat Modern}

Kemajuan ilmu pengetahuan dan teknologi telah mengakibatkan munculnya perubahan dalam masyarakat. Semakin maju perkembangan dalam masyarakat maka semakin banyak pula keperluan yang harus dipenuhi. Masyarakat modern dalam lingkungan kebudayan ditandai dengan perkembangan kemajuan ilmu dan teknologi untuk menghadapi keadaan sekitarnya. Menurut R. Tilaar (1979 : 17), ada beberapa indikator masyarakat modern dan disimpulkan oleh penulis (kelompok) sebagai berikut:

1. Saling mempengaruhi antara manusia dan lingkungan dengan tujuan menciptakan perubahan secara timbal balik;

2. Usaha untuk mengeksplorasi lingkungan dalam rangka untuk mengatasi tantangan-tantangan yang ditimbulkan dari lingkungan itu sendiri;

3. Dorongan rasa ingin tahu dan ingin mengatasi tantangan-tantangan menyebabkan manusia ingin mengusasi lingkungan;

4. Berpikir lebih objektif dan rasional; dan 
5. Selalu berusaha untuk memahami semua gejala yang dihadapi dan bagaimana mengorganisasikannya sehingga kehidupannya lebih baik.

Dalam masyarakat modern segala sesuatu diusahakan atau dikerjakan dengan sungguh-sungguh serta rasional sehingga menyebabkan selalu timbul pertanyaan dalam masyarakat apakah kegunaan sesuatu bagi usaha menguasai lingkungan sekitarnya. Akibat dari kehidupan tersebut, maka akan timbul sikap dalam masyarakat modern, diantaranya: 1) Terlalu percaya dengan peralatan dan teknik yang berjalan secara mekanis sebagai satu hasil pemikiran manusia (Ilmu pengetahuan); 2) Dalam hal ini masyarakat tergolong dalam paham positivisme Berbuat dan bertindak sesuai dengan rencana yang terperinci sehingga tidak jarang manusia dikendalikan oleh rencana yang disusunnya; dan 3) Timbal rasa kehilangan orientasi dan jati diri yang dapat melemahkan kehidupan bathin dan keagamaan.

Tanpa disadari masyarakat modern semakin tergantung pada alat dan teknologi yang diciptakan untuk menguasai dunia sekitarnya. Tidak jarang mereka kehilangan identitas karena sudah dikuasai oleh mekanisme yang mereka ciptakan sehingga mereka hidup tanpa jiwa dan tanpa kekuasaan. Dalam masyarakat modern (komplekpenduduk rapat) kompleksitas dan kerapatan pendudukak yang tinggi membuat mereka kurang sensitive terhadap emosional mereka apalagi masalah keagamaan mereka. Mereka cenderung ragu-ragu dalam memilih kepercayaan (Imran Manan: 1989 : 53). Yang paling fundamental dalam masyarakat modern adalah kepercayaan akan kemajuan ilmu pengetahuan. Bagi mereka, masa depan bersifat terbuka. Mereka percaya bahwa kondisi kemanusiaan, fisik, spiritual dapat diperbaiki dengan penggunaan sain dan teknologi.

Beberapa akibat dari kehidupan masyarakat modern adalah mereka terasing secara kehidupan social yang disebabkan oleh pertumbuhan urbanisme yang mendorong mobilitas dan melemahkan ikatan-ikatan kekeluargaan.

\section{Masyarakat Sederhana (Tradisional)}

Sikap berpikir subjektif yang menyatukan dirinya dalam memahami gejala yang timbul merupakan salah satu ciri masyarakat yang hidup dalam lingkungan yang sederhana. Masyarakat sederhana (tradisional) masih bersikap untuk berpikir secara massif (pola pikir yang tidak objektif dan rasional) untuk menganalisis, menilai dan menghubungkan suatu gejala dengan gejala yang lain. Manusia yang hidup tradisional (sederhana) biasanya masih ditandai dengan sikap berpikir analogis dengan mengadakan generalisasi, penggunaan waktu secara subjektif serta kurang mengenal waktu secara fisik.

Masyarakat sederhana menurut Robert Redfield dalam Imran Manan (1983 : 52) mengistilahkannya dengan "Folk Sociaty" yaitu masyarakat yang kecil, homogen, sangat terintegrasi, terasing, solidaritas kelompok yang tinggi, pembagian kerja yang sederhana, sebagian anggota masyarakat memiliki pengetahuan dan perhatian yang sama dan biasa dengan pemikiran, sikap-sikap dan aktivitas dari seluruh anggota masyarakat. Komuniktas masyarakat sederhana menimbang segala-galanya dengan prinsip-prinsip yang telah baku, mereka cendrung untuk berubah sangat lambat.

\section{Pendidikan dalam Mayarakat Sederhana Dan Modern}

Sangat berbeda dengan masyarakat modern, anak-anak masyarakat sederhana turut serta secara aktif dalam kehidupan masyarakat. Dari umur muda mereka diharapka mempunyai tanggung jawab sesuai dengan kekuatan dan pengalamannya. Masyarakat sederhana mempunyai pengetahuan yang kurang terspesialisasi dan sedikit EISSN 2657-0289 $\quad$ Lembaga Penelitian dan Penerbitan Hasil Penelitian Ensiklopedia 33 
keterampilan yang diajarkan membuat mereka tiada keperluan rasanya untuk menciptakan institusi yang terpisah bagi pendidikan sepeti sekolah. Sebagai gantinya anak-anak memperoleh warisan budaya dengan mengamati dan meniru orang dewasa dalam berbagai kegiatan seperti upacara, berburu, pertanian dan panen. Dalam kebudayaan masyarakat sederhana agen pendidikan yang formal termasuk di dalamnya kelauarga dan kerabat. Sedangkan sekolah muncul relative terlambat dalam lingkungan masyarakat sederhana. Adapun beberapa kondisi menurut Imran Manan (1989: 57) yang mendorong timbulnya lembaga pendidikan (sekolah) dalam masyarakat sederhana adalah:

1. Perkembangan agama dan kebutuhan untuk mendidik para calon ulama, pendeta.

2. Pertumbuhan dari dalam (lingkungan masyarakat itu sendiri) atau pengaruh dari luar.

3. Pembagian kerja dalam masyarakat yang menuntut keterampilan dan dan teknik khusus.

4. Konflik dalam masyarakat yang mengancam nilai-nilai tradisional dan akhirnya menuntut pendidikan untuk menguatkan penerimaan nilai-nilai warisan budaya.

Untuk mempelajari sesuatu biasanya anak-anak dalam masyarakat sederhana akan pergi kepada orang yang mereka anggap ahlinya. Mereka pempelajrinya tidak hanya hal tersebut secara universal disetujui bahwa ada hal-hal tertentu yang harus diketahui untuk perkembangan mereka dan hubungannya dengan kehidupan mereka masa sekarang dan akan dating. Artinya mereka belajar untuk kelangsungan hidupnya. Dalam mempelajari keterampilan anak-anak masyarakat sederhana selalu memiliki hubungan yang intim dengan visi orang dewasa, sehingga menimbulkan nilai-nilai kekeluargaan yang erat di antara mereka. Begitu juga dengan guru-guru, sangat terikat tidak hanya dengan murd-murudnya, yang mungkin anggota kerabatnya, tetapi juga kepada hasil dari apa yang diajarkannya. Jika ia gagal mengkomunikasikan keterampilannya secara efektif, dia akan dapat merasakan langsung akibatnya dengan segera.

Suatu masyarakat sederhana tidak mempunyai orang yang khusus berfungsi mengajar. Anggota-anggota masyarakat yang lebih tua mengajar kelaurga yang muda, walupun untuk tujuan-tujuan tertentu, seperti untuk menjadi guru mengaji, sebagai penceramah, dll. Sebagai hasilnya mereka yang mengajar turut serta secara penuh dalam kehidupan masyarakat di sekitarnya, karena guru-guru dalam masyarakat langsung mempraktekkan apa yang mereka ajarkan, seperti seorang guru mengaji langsung mempraktekkan apa yang mereka ajarkan, seorang ahli bertani langsung mempraktekkan apa yang akan mereka wariskan (ajarkan) kepada pewarisnya, dan hal lainnya. Dalam masyarakat sederhana pembelajaran menjadi lebih mudah sebab objek pembelajaran selalu dapat diperoleh. Walaupun begitu di sejumlah masyarakat sederhana ada juga sejumlah pengetahuan khusus yang mesti diajarkan dengan jelas, karena pengetahuan ini dipercayai menjamin kelangsungan dan kesuburan masyarakat. Sedangkan dalam masyarakat modern pendidikan memisahkan anak dari orang tuanya untuk memperoleh ketampilan (ilmu pengetahuan dan teknologi) serta akan membutuhkan waktu yang lebih panjang dari pada masyarakat sederhana. Dengan didirikannya lemabaga-lembaga formal (sekolah) membuat mereka lebih banyak terpisah dengan lingkungan masyarakat nmereka sedniri. Hal ini mengakibatkan anakanak dalam masyarakat meodern akan terasing dengan lingkungan masyarakatnya yang pada akhirnya akan mengurangi kepedulian diantara mereka. 
Akan tetapi kebanyakan tenaga pengejar (guru) dalam masyarakat modern cenderung mangajarkan sesuatu kepada muridnya jauh dengan realita yang ada. Sebagai contoh seorang guru bidang ekonomi yang mengajarkan cara menjadi manager keuangan, tidak akan terlibat langsung menjadi manager keuangan. Hal ini berimplikasi kepada jauhnya sesuatu apa yang mereka pelajari dari diri dan lingkungan mereka sendiri. Anak-anak dalam masyarakat modern cenderung berada dibawah tekanan yang besar dari orang tua dan guru-gurunya untuk menguasai pelajaran yang ditentukan dan dalam waktu yang telah ditentukan. Gejala ini akan berpotensi menimbulkan gejala kelainan mental jika hasil yang akan dicapai terlalau berat dibandingkan dengan kemampuan anak.

\section{Penutup}

Satu perbedaan yang sangat mendasar antara pendidikan dalam masyarakat sederhana dengan masyarakat modern adalah pergeseran dari kebutuhan individu untuk mempelajari sesuatu yang disetujui oleh setiap orang untuk kelangsungan hidupnya baik masa sekarang maupun masa akan datang. Semakin besar pengetahuan dan kompleks keterampilan yang akan dipelajari maka semakin lama waktu diperlukan untuk kelangsungan kehidupan bermasyarakat. Tugas pendidikan dalam masyarakat adalah membangkitkan rasa ingin tahu intelektual, yaitu perhatian terhadap pengetahuan yang terpisah dari aplikasi praktisnya. Hal ini sangatlah tidah mudah, karena diperlukan sikap, disiplin dan intelektual yang tidak bersifat pragmatis, instant dan serba cepat. Dengan adanya perbandingan pendidikan dalam masyarakat ini dieperolah perbandingan yang lebih seimbang kritis mengenai sisstem pendidikan kita. Jelas, bahwa dalam pendidikan tidak bias memindahkan praktek-praktek yang komplek kedalam kebudayaan yang lebih komplek dan besar dan mengharapkan akan hasil. Sebaliknya sukses masyarakat sederhana dalam mengurus aspek-aspek tertentu dalam mendorong pendidikannya, akan mendorong kita untuk mengatasi masalahmasalah pendidikan kita seperti masalah mengintegrasikan anak-anak kedalam komunitas kedalam lingkungannya dan membangkitkan minat, motivasi serta perhatian siswa selama masa pendidikan merupakan permasalahan-permasalahan yang perlu dicarai solusinya dengan prespektif dan optimisme yang lebih besar.

\section{Daftar Pustaka}

Azra, Azyumardi, (2002), Paradigma Baru Pendidikan Nasional Rekonstruksi dan Demokratisasi, Buku Kompas, Jakarta.

Manan, Imran (1989), Anthropologi Pendidikan (Suatu Pengantar), Departemen P \& K, PP-LPTK, Jakarta.

Manan, Imran, (1989), Dasar-dasar Sosial Budaya Pendidikan, Departemen P \& K, PP-LPTK, Jakarta.

Tillar. R, (1979), Pendidikan dan Pengembangan Masyarakat, Departemen Pendidikan \& Kebudayaan, Jakarta. 